\title{
Effect of seminal plasma infusion into the vagina on the normalization of endometrial epidermal growth factor concentrations and fertility in repeat breeder dairy cows
}

\author{
Dagvajamts BADRAKH ${ }^{1)}$, Yojiro YANAGAWA ${ }^{2)}$, Masashi NAGANO ${ }^{2)}$ and Seiji KATAGIRI ${ }^{3)}$ \\ 1) Laboratory of Theriogenology, Department of Clinical Sciences, Graduate School of Veterinary Medicine, \\ Hokkaido University, Sapporo 060-0818, Japan \\ ${ }^{2}$ Laboratory of Theriogenology, Department of Clinical Sciences, Faculty of Veterinary Medicine, Hokkaido University, \\ Sapporo 060-0818, Japan \\ ${ }^{3)}$ Department of Veterinary Environmental Sciences, Faculty of Veterinary Medicine, Hokkaido University, \\ Sapporo 060-0818, Japan
}

\begin{abstract}
Epidermal growth factor (EGF) concentrations in the uterus show two peaks on days 2-4 and 13-14 during the estrous cycle in fertile cows. Loss of the two peaks has been linked to reduced fertility in repeat breeder cows. This study aimed to examine the effect of seminal plasma (SP) on normalizing endometrial EGF concentrations and restoring fertility in repeat breeder cows with low EGF concentrations on day 3. In study 1, we examined the effect of the deposition sites (the vagina and uterus) of SP on the endometrial EGF concentrations in repeat breeder cows. SP infusion into the vagina, but not uterus, on the first day of the estrus cycle (day 0) normalized the endometrial EGF concentrations ( $\geq 4.7 \mathrm{ng} / \mathrm{g}$ tissue weight) on day 3. In study 2, the effect of SP volume $(0.5$ and $10 \mathrm{ml}$ of SP and $0.5 \mathrm{ml}$ of SP diluted to $10 \mathrm{ml})$ on EGF concentrations was examined. All groups with SP infusion had increased EGF concentrations on day 3, and cows with $10 \mathrm{ml}$ of SP and 0.5 $\mathrm{ml}$ of SP diluted to $10 \mathrm{ml}$ showed the highest levels of EGF concentrations. In study 3, we examined the effect of SP infusion on fertility. SP infusion normalized two peaks of endometrial EGF concentrations in about $60 \%$ of repeat breeder cows and produced more pregnancies than the controls (44.4 vs. 19.4\%). Therefore, we concluded that SP may contain an activity to normalize the EGF profile and restore fertility in repeat breeder cows with altered EGF profiles.
\end{abstract}

Key words: Embryonic loss, Endometrial biopsy, Epidermal growth factor (EGF), Repeat breeder, Seminal plasma

(J. Reprod. Dev. 66: 149-154, 2020)

E pidermal growth factor (EGF) is a key factor that regulates uterine function and embryonic development $[1,2]$. Studies on the regulation of EGF in the uteri of mice and rats have found that estrogen is the primary regulator of EGF production in the endometrium [2-5]. In fertile cows, the endometrial EGF concentrations in the uterine endometrium show two peaks at days $2-4$ and 13-14 of the estrous cycle, and the loss of these peaks, even in the presence of an apparently normal estrous (ovarian) cycle, indicates a reduction of fertility in dairy cows [6-8]. These peaks were not found in about $70 \%$ of Holstein repeat breeder cows and $25 \%$ of Holstein cows 60 days postpartum $[6,8]$. Furthermore, examining the EGF concentrations on the day of the first peak (Day 3) appropriately determined the endometrial EGF profile because the loss and recovery of the two peaks of the endometrial EGF concentrations coincide in most cases $[8,9]$.

The loss of the peaks in the endometrial EGF concentrations during

Received: November 17, 2019

Accepted: December 28, 2019

Advanced Epub: January 28, 2020

(C)2020 by the Society for Reproduction and Development

Correspondence: S Katagiri (e-mail: katagiri@vetmed.hokudai.ac.jp)

This is an open-access article distributed under the terms of the Creative Commons Attribution Non-Commercial No Derivatives (by-nc-nd) License. (CC-BY-NC-ND 4.0: https://creativecommons.org/licenses/by-nc-nd/4.0/) the estrous cycle may impair the regulation of uterine functions and, in turn, cause asynchrony between the uterus and the blastocysts upon their entry [10-12]. A maternal supply of EGF from the endometrium may also play a role in the elongation of bovine embryos (Days 14-16) [13]. Accordingly, an alteration of the endometrial EGF concentrations has been linked to an increased frequency of embryo loss after artificial insemination (AI) in repeat breeder cows [14, 15] and a failure of pregnancy after embryo transfer in apparently healthy recipients [9].

Some endocrine changes have been described in repeat breeder cows as a slow rise or low peak of plasma estradiol concentrations, a delayed luteinizing hormone surge in the peri-ovulatory period, and a slow rise or low plasma progesterone levels during the luteal phase $[10,16]$. These changes may cause endometrial EGF profile alterations in uteri because EGF synthesis is regulated by estrogen together with progesterone [1-3]. Therefore, we developed a treatment protocol using a high dose of estradiol benzoate $(5 \mathrm{mg})$ with an intravaginal progesterone-releasing device in repeat breeder cows. The treatment normalized the endometrial EGF profile and restored fertility in about 70 and $60 \%$ of repeat breeder cows, respectively [17]. However, the efficacy of treatment to normalize the endometrial EGF concentrations varies considerably between 30 and $85 \%$ depending on the herds located at different farms, for currently unknown reasons. Furthermore, the use of estrogen products in animals intended for 
consumption has been restricted in many countries and regions. Therefore, additional treatment options are needed.

Previous studies have indicated that seminal plasma (SP) may improve fertility by modulating uterine function and environment in rodents, pigs, horses, and humans [18-22]. In mice, SP factors initiate the inflammatory response and activate the synthesis of inflammatory cytokines when they interact with estrogen-primed uterine epithelial cells [23-25]. These cytokines activated by SP induce an influx of inflammatory cells into the uterine endometrium that have roles in remodeling the endometrial tissue, activating maternal immune accommodation of pregnancy, and promoting the development of pre-implantation embryos [26-28]. In pigs, conception and farrowing rates were greater in females that received AI with SP than AI with extender alone [29]. Exposure of the uterus to SP resulted in an increase in the proportion of viable embryos from 77 to $91 \%$ (phosphate-buffered saline, PBS vs. SP) in gilts when embryo recovery data on days 5 and 9 were combined, leading to a $58 \%$ increase in the number of viable embryos recovered from the gilts after SP treatment [30]. In horses, SP reduces sperm binding to polymorphonuclear neutrophils after AI [21]. This SP action may improve fertility when spermatozoa are inseminated into the uterus with mild inflammation typically during the early postpartum period.

This circumstantial evidence in different species prompted us to examine whether SP affects the endometrial regulatory network, which includes EGF, and normalizes the EGF profile in repeat breeder cows. A large-scale trial, in which SP was infused into the uterus, failed to improve the pregnancy rate in both dairy and beef cows [31]. In natural copulation, semen is deposited into the vagina in cattle, and into the uterus or cervix in species where SP has facilitated pregnancy. The deposition site of semen at natural copulation should be taken into consideration when the effect of SP in female genital tracts is evaluated. Therefore, the present study first examined the effect of the deposition sites of SP, the uterus and vagina, on the endometrial EGF concentrations in repeat breeder cows (study 1). Then, the effect of SP volume on the normalization of the endometrial EGF concentrations was examined (study 2). Finally, the effect of SP infusion into the vagina on the fertility of repeat breeder cows was examined (study 3 ).

\section{Materials and Methods}

\section{Animals}

All animal experiments were conducted according to the Care and Use of Experimental Animals protocol of Hokkaido University, Japan (Experimental protocol \#16-0071, 19-0030). The present study used four fertile cows with normal EGF concentrations ( $\geq 4.7 \mathrm{ng} / \mathrm{g}$ tissue weight) and 107 repeat breeder cows with low endometrial EGF concentrations on day 3 of the previous estrus cycle. These repeat breeders were diagnosed by local practitioners using the criteria of failing to conceive after three or more AIs without a detectable clinical abnormality in terms of the estrous cycle and genital organs. All cows were then confirmed to meet the definition of repeat breeder cows through additional examinations, including uterine morphology by transrectal ultrasonography [32], uterine cytology by cytobrush [33], and oviductal patency by tubal insufflation [34], conducted by one of the authors of this study before enrollment. Repeat breeder cows with normal uterine morphology and oviductal patency and a proportion of polymorphonuclear leucocytes in uterine cytology of $<6 \%$ [35] were used. Uterine morphology was examined using a real-time B-mode ultrasound scanner (HS-1500, Honda electronics, Toyohashi, Japan) and judged as normal according to the criteria of no fluids or a small volume of black fluids in a spoke wheel-shaped lumen with infoldings of the endometrium during the luteal phase [32]. Oviductal patency was tested using an Atom PA-200 (Atom Medical, Tokyo, Japan) and judged as normal when the air began to escape from the abdominal os at $100-120 \mathrm{mmHg}$ and continued to escape until $60 \mathrm{mmHg}$ [34].

The endometrial EGF concentrations of the repeat breeder cows were then assessed on day 3 based on biopsy samples, and cows showing low EGF concentrations $(<4.7 \mathrm{ng} / \mathrm{g}$ tissue weight) were then selected for this study. All repeat breeder cows were multiparous lactating Holstein cows ( $>10,000 \mathrm{~kg}$ of 305-day fat-corrected milk) three to nine years of age and 145 to 250 days post-partum on the day of the first biopsy for EGF measurement. No cows received therapeutic treatment for infertility.

\section{Biopsy of uterine endometrial tissues}

Uterine endometrial tissues were obtained by biopsy using a biopsy instrument (Fujihira Industry, Tokyo, Japan) with caudal epidural anesthesia ( $3 \mathrm{ml}$ of $2 \%$ lidocaine; $2 \%$ xylocaine, Fujisawa Pharmaceutical, Osaka, Japan) as described previously [6]. Tissues were frozen in liquid nitrogen within $10 \mathrm{~min}$ of collection and stored at $-80^{\circ} \mathrm{C}$ until the EGF assay.

\section{Measurement of endometrial EGF concentrations and judgment of the EGF profile}

Uterine endometrial tissues were processed for the EGF assay as described previously [36] with a modification to increase the ratio of the extraction solution $(\mathrm{ml})$ to the tissue weight $(\mathrm{g})$ from 1:5 to 1:15 [14]. Concentrations of EGF in uterine tissue extracts were determined by a double-antibody sandwich EIA using 96-well microtiter plates [14]. Anti-human EGF mouse monoclonal antibody (R\&D Systems, Minneapolis, MN, USA) and anti-human EGF rabbit antiserum (Biogenesis, Poole, UK) were used as a solid-phase and detection antibody, respectively. Neither antibodies showed significant crossreactivity with other cytokines tested by manufacturers. The assay system was verified using increasing concentrations of recombinant bovine EGF. A linear regression analysis of recombinant bovine EGF concentrations and assay results gave $\mathrm{y}=0.96 \mathrm{x}+0.39, \mathrm{r}=$ 0.97 . The intra- and inter-assay coefficients of variation were 4.8 and $6.2 \%$, respectively. The sensitivity of the assay was $10 \mathrm{pg} / \mathrm{well}$.

In studies 1 and 2, endometrial EGF concentrations were determined via examination on day 3 , and profiles were considered normal when the concentration was $\geq 4.7 \mathrm{ng} / \mathrm{g}$ tissue weight $[8,14]$. For study 3 , the endometrial EGF profile was determined through three examinations (days 3, 7, and 14) and considered normal when the concentrations on all three days were within the normal range (day 3 : 4.7-13.5, day 7: 1.8-4.6, day 14: 4.9-14.9 ng/g tissue weight) [14].

\section{Preparation of SP samples}

Semen was collected twice a week from nine fertile Holstein bulls using an artificial vagina at a commercial AI center (Genetics 
Hokkaido, Tokachi Shimizu, Hokkaido, Japan). Two ejaculates were collected on each day usually with a $30 \mathrm{~min}$ interval. SP was separated by centrifugation at $1,000 \times \mathrm{g}$ for $10 \mathrm{~min}$, frozen at $-20^{\circ} \mathrm{C}$ and transported to Hokkaido University. There, all frozen SP samples were thawed and centrifuged at $5,000 \times \mathrm{g}$ for $20 \mathrm{~min}$ at $4^{\circ} \mathrm{C}$, and the resulting supernatants were used as SP samples. In study $1, \mathrm{SP}$ from three of the nine bulls was pooled and held in $0.5 \mathrm{ml}$ aliquots and stored at $-80^{\circ} \mathrm{C}$. In studies 2 and $3, \mathrm{SP}$ from the nine bulls (6-10 ejaculates per bull) was pooled and held in either 0.5 or 10 $\mathrm{ml}$ aliquots and stored at $-80^{\circ} \mathrm{C}$.

\section{Infusion of SP into the vagina and uterus}

At the time of infusion, SP was thawed and SP alone or diluted SP with PBS was aspirated with either a 5 or $10 \mathrm{cc}$ syringe. A disposable plastic AI catheter was attached to the syringe with either the SP sample or PBS (control). The AI catheter was introduced into either the vagina or uterus through the cervix. The SP or PBS was deposited into the vagina near the external orifice of the cervix or the uterine body. The AI catheter was gently withdrawn after the infusion.

\section{Study design}

All studies were conducted at commercial dairy farms in the Hokkaido prefecture, Japan, between April and June (studies 1 and 2 ) and September and December (study 3 ). The conception rates of cows in all farms were between 46.7 and $57.4 \%$ and were at similar levels during the study period.

\section{Study 1}

Repeat breeder cows were observed for estrus three times a day (day $0=$ estrus) and the endometrial EGF concentrations were examined on day 3. Eight repeat breeder cows with low endometrial EGF concentrations $(<4.7 \mathrm{ng} / \mathrm{g}$ tissue weight) were used during the next estrus cycle. In four repeat breeder cows, $0.5 \mathrm{ml}$ of SP was infused into the vagina $4 \mathrm{~h}$ after the first detection of standing estrus, while SP was infused into the uterus in the other four repeat breeder cows. In all repeat breeder cows, the endometrial EGF concentrations were determined on day 3 . The endometrial EGF concentrations of apparently healthy cows were determined on day 3 before recruitment for the study, and four cows with normal EGF concentrations $(\geq 4.7$ $\mathrm{ng} / \mathrm{g}$ tissue weight) on day 3 were used as fertile controls. Cows in the fertile control group were infused with $0.5 \mathrm{ml}$ of SP into the vaginas on the day of the next estrus, and were used for the examination of the endometrial EGF concentrations on day 3.

\section{Study 2}

The effect of different volumes of SP on the endometrial EGF concentrations was examined using 32 repeat breeder cows with a low endometrial EGF concentration on day 3. Repeat breeder cows were observed for estrus three times a day. SP alone $(0.5$ or $10 \mathrm{ml})$, $0.5 \mathrm{ml}$ of SP diluted to $10 \mathrm{ml}$ with PBS, or $10 \mathrm{ml}$ of PBS were infused into the vagina of the eight repeat breeder cows $4 \mathrm{~h}$ after the first detection of standing estrus. In all cows, the endometrial EGF concentrations were determined on day 3.

\section{Study 3}

The effect of SP infusion on the endometrial EGF profile and fertility was examined using 67 repeat breeder cows with a low endometrial EGF concentration on day 3. Cows were observed for estrus three times a day. In total, 36 and 31 repeat breeder cows were infused with $0.5 \mathrm{ml}$ of SP diluted to $10 \mathrm{ml}$ with PBS and $10 \mathrm{ml}$ of PBS (control), respectively, into the vagina $4 \mathrm{~h}$ after the first detection of standing estrus (day 0). The endometrial EGF concentrations were determined on days 3, 7, and 14. All repeat breeder cows were subjected to AI at the next estrus and pregnancy was diagnosed between days 50 and 60 .

\section{Data analysis}

Data were analyzed using computer software JMP Pro 14 data (SAS Institute Japan, Tokyo, Japan). In all studies, the endometrial EGF concentrations were compared using two-way ANOVA with repeated measure followed by Tukey's test (for three or more means) or Student's $t$-test (for two means) as post-hoc tests. The endometrial EGF concentrations of the cows in which EGF reached normal levels after infusion were compared using one-way ANOVA followed by Tukey's test. The rates of normalization of the EGF profile and pregnancy were compared by Fisher's exact test.

\section{Results}

\section{Study 1}

In all four fertile cows, the endometrial EGF concentrations at the first examination were at normal levels ( $\geq 4.7 \mathrm{ng} / \mathrm{g}$ tissue weight), and the EGF concentrations did not change after SP infusion (Table 1). All four cows conceived by one or two AIs after the study. In repeat breeder cows, the endometrial EGF concentrations at the first examination (before SP infusion) were at the same levels in both groups with SP infusion. When SP was infused into the vagina, the endometrial EGF concentrations increased to normal levels in three out of the four cows and were at the same levels as the fertile cows. However, the endometrial EGF concentrations of all four repeat breeder cows remained low when SP was infused into the uterus.

\section{Study 2}

The endometrial EGF concentrations at the first examination (before SP infusion) were similar in all four groups (Table 2). In three groups with SP infusion, the endometrial EGF concentrations on day 3 after the infusion increased to normal levels and were higher than those of the control group (PBS alone). However, the endometrial EGF concentrations of the normalized cows, in which the EGF concentrations reached normal levels after infusion, differed between the SP infusion groups. The EGF concentrations of the two groups with $10 \mathrm{ml}$ of SP and $0.5 \mathrm{ml}$ of SP diluted to $10 \mathrm{ml}$ were higher than those of $0.5 \mathrm{ml}$ of SP.

\section{Study 3}

The endometrial EGF concentrations of both the SP and control groups before infusion were at the same level (Table 3 ). The normalization rate of the endometrial EGF profile in the SP infusion group was higher than that of the controls (58.3 vs. $22.6 \%, \mathrm{P}<$ 0.05). Accordingly, the endometrial EGF concentrations on days 3 and 14 after SP infusion were greater than those of the controls $(\mathrm{P}<0.05)$. However, the endometrial EGF concentrations in cows 
Table 1. The effect of seminal plasma (SP) infusion into the vagina and uterus on the endometrial epidermal growth factor (EGF) concentrations

\begin{tabular}{lccccc}
\hline Cows ${ }^{\#}$ & $\mathrm{n}$ & $\begin{array}{c}\text { Sites of SP } \\
\text { infusion }\end{array}$ & $\begin{array}{c}\text { No. (\%) of cows with normal } \\
\text { EGF concentrations on day } 3 \\
\text { after infusion }\end{array}$ & \multicolumn{2}{c}{$\begin{array}{c}\text { Endometrial EGF concentrations } \\
\text { (ng/g tissue weight) }\end{array}$} \\
\cline { 5 - 6 } Repeat breeders & 4 & Uterus & $0(0)$ & Before infusion & After infusion \\
\hline Fertile & 4 & Vagina & $3(75)$ & $1.86 \pm 0.64^{\mathrm{A}}$ & $1.74 \pm 0.71^{\mathrm{A}}$ \\
& 4 & Vagina & $4(100)$ & $2.01 \pm 0.81^{\mathrm{aA}}$ & $6.31 \pm 2.25^{\mathrm{bB}}$ \\
\hline
\end{tabular}

Values are means \pm SDs. ${ }^{\#}$ All repeat breeder cows showed low EGF concentrations before infusion while all four cows in the fertile group had EGF concentrations within the normal range before infusion. The normal range of endometrial EGF concentrations on day 3 is $4.7-13.5 \mathrm{ng} / \mathrm{g}$ tissue weight [14]. ${ }^{\mathrm{a}, \mathrm{b}}$ Means with different letters within the same row differ $(\mathrm{P}<$ $0.01) .{ }^{A}, \mathrm{~B}$ Means with different letters within the same column differ $(\mathrm{P}<0.01)$.

Table 2. The effect of the volume of seminal plasma (SP) infused into the vagina on endometrial epidermal growth factor (EGF) concentrations

\begin{tabular}{ccccccc}
\hline \multirow{2}{*}{$\begin{array}{c}\text { SP } \\
(\mathrm{ml})\end{array}$} & $\begin{array}{c}\text { PBS } \\
(\mathrm{ml})\end{array}$ & $\mathrm{n}$ & $\begin{array}{c}\text { No. (\%) of cows with normal } \\
\text { EGF concentrations on day } 3 \\
\text { after infusion }\end{array}$ & & \multicolumn{2}{c}{ Endometrial EGF concentrations (ng/g tissue weight) } \\
\cline { 5 - 7 } & & & $4(50.0)$ & & \multicolumn{2}{c}{ After infusion } \\
\cline { 5 - 7 } & & 8 & $5(62.5)$ & $1.83 \pm 0.94^{\mathrm{a}}$ & $4.84 \pm 1.54^{\mathrm{bB}}$ & $6.01 \pm 0.76^{\mathrm{A}}(4)$ \\
10 & 0 & 8 & $5(62.5)$ & $1.83 \pm 1.36^{\mathrm{a}}$ & $5.93 \pm 1.83^{\mathrm{bB}}$ & $7.21 \pm 0.61^{\mathrm{B}}(5)$ \\
0.5 & 9.5 & 8 & $2(25.0)$ & $1.84 \pm 1.34^{\mathrm{a}}$ & $5.91 \pm 2.29^{\mathrm{bB}}$ & $7.46 \pm 0.76^{\mathrm{B}}(5)$ \\
0 & 10 & 8 & $1.95 \pm 1.24$ & $2.55 \pm 1.92^{\mathrm{A}}$ & $5.35,5.86(2)$ \\
\hline
\end{tabular}

Values are means \pm SDs. ${ }^{*}$ The numbers in the parentheses are the number of cows with normalized EGF concentrations after infusion. The phosphate-buffered saline (PBS) infusion (control) group was excluded from statistical analysis due to its small number. ${ }^{\mathrm{a}, \mathrm{b}}$ Means with different letters within the same row differ $(\mathrm{P}<0.01) .{ }^{\mathrm{A}, \mathrm{B}}$ Means with different letters within the same column differ $(\mathrm{P}<0.01)$.

Table 3. The effect of seminal plasma (SP) infusion on the normalization rates of the epidermal growth factor (EGF) profiles and fertility in repeat breeder cows

\begin{tabular}{|c|c|c|c|c|c|c|}
\hline \multirow{3}{*}{ Groups } & \multirow{3}{*}{$\begin{array}{l}\text { No. (\%) of cows with the } \\
\text { indicated EGF profile } \\
\text { after infusion }\end{array}$} & \multirow{3}{*}{$\begin{array}{c}\text { Conception rate } \\
(\%)\end{array}$} & \multicolumn{4}{|c|}{ Endometrial EGF concentrations (ng/g tissue weight) } \\
\hline & & & \multirow{2}{*}{$\begin{array}{l}\text { Before infusion } \\
\text { (Day 3) }\end{array}$} & \multicolumn{3}{|c|}{ After infusion } \\
\hline & & & & Day 3 & Day 7 & Day 14 \\
\hline \multirow[t]{3}{*}{$\overline{\mathrm{SP}}$} & Normal $21(58.3)^{\mathrm{A}}$ & $13(61.9)^{\mathrm{C}}$ & $1.97 \pm 1.02$ & $8.21 \pm 1.08^{a}$ & $1.39 \pm 1.10^{b}$ & $8.41 \pm 1.50^{\mathrm{a}}$ \\
\hline & Altered $15(41.7)$ & $3(20.0)^{\mathrm{D}}$ & $1.95 \pm 0.77$ & $2.18 \pm 0.97$ & $1.81 \pm 1.73$ & $2.97 \pm 1.68$ \\
\hline & $36(100)$ & $16(44.4)^{\mathrm{A}}$ & $1.96 \pm 0.81$ & $6.08 \pm 1.96^{\mathrm{aA}}$ & $1.89 \pm 0.09^{b}$ & $6.18 \pm 1.41^{\mathrm{aA}}$ \\
\hline \multirow[t]{3}{*}{ PBS } & Normal $7(22.6)^{B}$ & $3(42.9)$ & $1.81 \pm 0.97$ & $7.24 \pm 1.93^{\mathrm{a}}$ & $1.47 \pm 1.41^{\mathrm{b}}$ & $6.86 \pm 1.88^{\mathrm{a}}$ \\
\hline & Altered $24(77.4)$ & $3(12.5)$ & $1.87 \pm 1.14$ & $1.99 \pm 0.87$ & $2.37 \pm 1.36$ & $2.07 \pm 1.55$ \\
\hline & $31(100)$ & $6(19.4)^{\mathrm{B}}$ & $1.86 \pm 1.01$ & $2.67 \pm 0.98^{\mathrm{B}}$ & $1.92 \pm 0.16$ & $2.88 \pm 0.86^{\mathrm{B}}$ \\
\hline
\end{tabular}

Values are means \pm SDs. ${ }^{A}, \mathrm{~B}$ Means with different letters within the same EGF profile of SP and phosphate-buffered saline (PBS) groups differ $(\mathrm{P}<0.05)$. C, D Means with different letters between the different EGF profiles within the same infusion groups differ $(\mathrm{P}<0.05)$. ${ }^{\mathrm{a}, \mathrm{b}}$ Means with different letters within the same row differ $(\mathrm{P}<0.05)$.

showing a normal EGF profile after infusions of SP and PBS were at similar levels on both days 3 and 14. The conception rate after SP infusion was greater than that of the controls (44.4 vs. $19.4 \%, \mathrm{P}<$ 0.05 ). Among those in which the EGF profile was normalized after SP infusion, the conception rate of the cows showing the normal EGF profile was greater than that of the cows with an altered EGF profile (61.9 vs. $20.0 \%, \mathrm{P}<0.05)$.

\section{Discussion}

In the present study, we demonstrated that SP normalized the endometrial EGF profile during the estrous cycle and improved fertility in repeat breeder cows with an altered EGF profile when infused into the vagina but not the uterus. In general, SP induces an inflammatory response leading to changes in the endometrial cytokine and growth factor network in the uterus and may improve fertility in pigs [30, 37], rodents [28], horses [38], and humans [39]. However, 
in cattle, large-scale studies have failed to demonstrate a beneficial effect of SP infusion into the uterus on fertility [31, 40]. The results of these studies appear to be inconsistent with our findings. However, our study design differs in two ways from these studies [31, 40]. First, we used a specific group of cows, namely repeat breeder cows with abnormal EGF profiles in the endometrium, while the previous studies targeted apparently healty cows or all cows in a herd. The results of study 3 and those of previous studies $[9,15]$ indicate that the improvement of fertility in the repeat breeder cows could be attributed to the normalization of the endometrial EGF concentrations. This effect of SP on fertility may not have been detectable in the previous studies $[31,40]$ because the majority of apparently normal cows showed a normal EGF profile before SP infusion.

The second way in which our study design differs from those of previous studies $[31,40]$ is the site of SP deposition. In study 1 , we examined the effect of SP deposition sites (uterus and vagina) and found that SP should be deposited into the vagina to normalize the endometrial EGF concentrations. In natural mating, semen is deposited into the uterus or cervix of animals where uterine SP infusion has previously been linked to an improvement in fertility, while semen is deposited into the vagina in cattle. The present study demonstrated that SP infusion into the vagina but not the uterus increased endometrial EGF concentrations in repeat breeder cows. Therefore, to examine the effect of SP on fertility in apparently healthy cows, SP should be infused into the vagina.

We examined the effect of different SP volumes on the normalization of endometrial EGF concentrations in study 2. In study 1, we used $0.5 \mathrm{ml}$ of SP as per previous studies [31, 40] and due to the limited volume of SP available as it was collected from young bulls that provide 2-3 $\mathrm{ml}$ of SP per ejaculate. However, the ejaculates of older bulls contain a larger volume $(4-6 \mathrm{ml})$ of SP. Therefore, we examined the effect of SP with an increased volume of $10 \mathrm{ml}$ in study 2. This volume had a greater effect on the endometrial EGF concentrations compared to $0.5 \mathrm{ml}$ of SP. Interestingly, when 0.5 $\mathrm{ml}$ of SP was diluted to $10 \mathrm{ml}$, the effect on the endometrial EGF concentrations was the same as that of $10 \mathrm{ml}$ of SP. These results indicate that $0.5 \mathrm{ml}$ of SP contains sufficient activity to exhibit a maximal effect of normalizing endometrial EGF concentrations. The results also indicate that infusion volumes are important to obtain the maximal effect. For example, the area of vaginal mucosa being exposed to SP may affect the degree of the endometrial response in terms of EGF production.

The mechanism by which SP infusion into the vagina changes EGF concentrations in the uterus is unknown. It is unlikely that SP is transported to the uterus to normalize EGF concentrations because SP infusion into the uterus failed to normalize these. At present, evidence that SP protein improves fertility seems to be related to sperm function and viability or the direct effect on the uteri found in other species [28, 41, 42] and cultured cells [43, 44]. Furthermore, a limited amount of information is available regarding the function of the vagina in the establishment of pregnancy. Further study to identify the seminal factors responsible for the activity to normalize the endometrial EGF profile would help to elucidate this mechanism.

To our knowledge, this is the first report demonstrating that SP infusion into the vagina can modulate uterine growth factor expression associated with uterine function and improve fertility. The function of
SP identified in the present study may explain, in part, the difference in conception rates between natural mating and AI. This SP function appears to be beneficial in cows with reduced fertility, including repeat breeders and early postpartum high yielding cows, but the effect of SP infusion into the vagina of apparently fertile cows with the normal EGF profile remains to be examined. Nevertheless, the SP function is not utilized in current AI-based reproductive management techniques in cattle but could contribute to improve fertility in dairy cows by moving repeat breeder cows back into the pool of fertile cows.

\section{Acknowledgements}

This study was supported by Grants-in-Aid for Scientific Research from the Japan Society for the Promotion of Science (Nos. $16 \mathrm{H} 05032$ and 19H00964) and by Grants-in-Aid for the Promotion of the Livestock Industry from the Japan Racing Association.

\section{References}

1. Brigstock DR. Growth factors in the uterus: steroidal regulation and biological actions. Baillieres Clin Endocrinol Metab 1991; 5: 791-808. [Medline] [CrossRef]

2. Paria BC, Song H, Dey SK. Implantation: molecular basis of embryo-uterine dialogue. Int J Dev Biol 2001; 45: 597-605. [Medline]

3. DiAugustine RP, Petrusz P, Bell GI, Brown CF, Korach KS, McLachlan JA, Teng CT. Influence of estrogens on mouse uterine epidermal growth factor precursor protein and messenger ribonucleic acid. Endocrinology 1988; 122: 2355-2363. [Medline] [CrossRef]

4. Huet-Hudson YM, Chakraborty C, De SK, Suzuki Y, Andrews GK, Dey SK. Estrogen regulates the synthesis of epidermal growth factor in mouse uterine epithelial cells. Mol Endocrinol 1990; 4: 510-523. [Medline] [CrossRef]

5. Falck L, Forsberg JG. Immunohistochemical studies on the expression and estrogen dependency of EGF and its receptor and C-fos proto-oncogene in the uterus and vagina of normal and neonatally estrogen-treated mice. Anat Rec 1996; 245: 459-471. [Medline] [CrossRef]

6. Katagiri S, Takahashi Y. Changes in EGF concentrations during estrous cycle in bovine endometrium and their alterations in repeat breeder cows. Theriogenology 2004; 62: 103-112. [Medline] [CrossRef]

7. Katagiri S, Moriyoshi M, Takahashi Y. Low incidence of an altered endometrial epidermal growth factor (EGF) profile in repeat breeder Holstein heifers and differential effect of parity on the EGF profile between fertile Holstein (dairy) and Japanese Black (beef) cattle. J Reprod Dev 2013; 59: 575-579. [Medline] [CrossRef]

8. Katagiri S, Moriyoshi M, Yanagawa Y. Endometrial epidermal growth factor profile and its abnormalities in dairy cows. J Reprod Dev 2016; 62: 465-470. [Medline] [CrossRef]

9. Katagiri S. Relationship between endometrial epidermal growth factor and fertility after embryo transfer. J Reprod Dev 2006; 52(suppl): S133-S137.

10. Erb RE, Garverick HA, Randel RD, Brown BL, Callahan CJ. Profiles of reproductive hormones associated with fertile and nonfertile inseminations of dairy cows. Theriogenology 1976; 5: 227-242. [Medline] [CrossRef]

11. Kimura M, Nakao T, Moriyoshi M, Kawata K. Luteal phase deficiency as a possible cause of repeat breeding in dairy cows. Br Vet $J$ 1987; 143: 560-566. [Medline] [CrossRef]

12. Shelton K, Gayerie De Abreu MF, Hunter MG, Parkinson TJ, Lamming GE. Luteal inadequacy during the early luteal phase of subfertile cows. J Reprod Fertil 1990; 90: 1-10. [Medline] [CrossRef]

13. Kliem A, Tetens F, Klonisch T, Grealy M, Fischer B. Epidermal growth factor receptor and ligands in elongating bovine blastocysts. Mol Reprod Dev 1998; 51: 402-412. [Medline] [CrossRef]

14. Katagiri S, Takahashi Y. Potential relationship between normalization of endometrial epidermal growth factor profile and restoration of fertility in repeat breeder cows. Anim Reprod Sci 2006; 95: 54-66. [Medline] [CrossRef]

15. Katagiri S, Moriyoshi M. Alteration of the endometrial EGF profile as a potential mechanism connecting the alterations in the ovarian steroid hormone profile to embryonic loss in repeat breeders and high-producing cows. J Reprod Dev 2013; 59: 415-420. [Medline] [CrossRef]

16. Båge R, Gustafsson H, Larsson B, Forsberg M, Rodríguez-Martínez H. Repeat breeding in dairy heifers: follicular dynamics and estrous cycle characteristics in relation to 
sexual hormone patterns. Theriogenology 2002; 57: 2257-2269. [Medline] [CrossRef]

17. Katagiri S, Takahashi Y. A progestin-based treatment with a high dose of estradiol benzoate normalizes cyclic changes in endometrial EGF concentrations and restores fertility in repeat breeder cows. $J$ Reprod Dev 2008; 54: 473-479. [Medline] [CrossRef]

18. O WS, Chen HQ, Chow PH. Effects of male accessory sex gland secretions on early embryonic development in the golden hamster. J Reprod Fertil 1988; 84: 341-344. [Medline] [CrossRef]

19. Gooneratne AD, Thacker PA. Effect of intrauterine infusion of sperm antigens on gilt fertility. Theriogenology 1989; 31: 1221-1226. [Medline] [CrossRef]

20. Tremellen KP, Valbuena D, Landeras J, Ballesteros A, Martinez J, Mendoza S, Norman RJ, Robertson SA, Simón C. The effect of intercourse on pregnancy rates during assisted human reproduction. Hum Reprod 2000; 15: 2653-2658. [Medline] [CrossRef]

21. Alghamdi AS, Foster DN, Troedsson MHT. Equine seminal plasma reduces sperm binding to polymorphonuclear neutrophils (PMNs) and improves the fertility of fresh semen inseminated into inflamed uteri. Reproduction 2004; 127: 593-600. [Medline] [CrossRef]

22. Robertson SA. Seminal fluid signaling in the female reproductive tract: lessons from rodents and pigs. J Anim Sci 2007; 85(Suppl): E36-E44. [Medline] [CrossRef]

23. Sanford TR, De M, Wood GW. Expression of colony-stimulating factors and inflammatory cytokines in the uterus of CD1 mice during days 1 to 3 of pregnancy. J Reprod Fertil 1992; 94: 213-220. [Medline] [CrossRef]

24. Robertson SA, Mayrhofer G, Seamark RF. Uterine epithelial cells synthesize granulocyte-macrophage colony-stimulating factor and interleukin- 6 in pregnant and nonpregnant mice. Biol Reprod 1992; 46: 1069-1079. [Medline] [CrossRef]

25. Robertson SA, Mau VJ, Tremellen KP, Seamark RF. Role of high molecular weight seminal vesicle proteins in eliciting the uterine inflammatory response to semen in mice. $J$ Reprod Fertil 1996; 107: 265-277. [Medline] [CrossRef]

26. Robertson SA, Mau VJ, Hudson SN, Tremellen KP. Cytokine-leukocyte networks and the establishment of pregnancy. Am J Reprod Immunol 1997; 37: 438-442. [Medline] [CrossRef]

27. Robertson SA, Sjöblom C, Jasper MJ, Norman RJ, Seamark RF. Granulocytemacrophage colony-stimulating factor promotes glucose transport and blastomere viability in murine preimplantation embryos. Biol Reprod 2001; 64: 1206-1215. [Medline] [CrossRef]

28. Robertson SA. Seminal plasma and male factor signalling in the female reproductive tract. Cell Tissue Res 2005; 322: 43-52. [Medline] [CrossRef]

29. Rozeboom KJ, Troedsson MHT, Hodson HH, Shurson GC, Crabo BG. The importance of seminal plasma on the fertility of subsequent artificial inseminations in swine. $J$ Anim Sci 2000; 78: 443-448. [Medline] [CrossRef]

30. O'Leary S, Jasper MJ, Warnes GM, Armstrong DT, Robertson SA. Seminal plasma regulates endometrial cytokine expression, leukocyte recruitment and embryo development in the pig. Reproduction 2004; 128: 237-247. [Medline] [CrossRef]

31. Odhiambo JF, Poole DH, Hughes L, Dejarnette JM, Inskeep EK, Dailey RA. Preg- nancy outcome in dairy and beef cattle after artificial insemination and treatment with seminal plasma or transforming growth factor beta-1. Theriogenology 2009; 72: 566-571. [Medline] [CrossRef]

32. Mee JF, Buckley F, Ryan D, Dillon P. Pre-breeding ovaro-uterine ultrasonography and its relationship with first service pregnancy rate in seasonal-calving dairy herds. Reprod Domest Anim 2009; 44: 331-337. [Medline] [CrossRef]

33. Kasimanickam R, Duffield TF, Foster RA, Gartley CJ, Leslie KE, Walton JS, Johnson WH. Endometrial cytology and ultrasonography for the detection of subclinical endometritis in postpartum dairy cows. Theriogenology 2004; 62: 9-23. [Medline] [CrossRef]

34. Kawata K, Koike T. Studies on the tubal patency of the cow: II. tuboinsufflation test in clinical cases. Jpn J Vet Res 1959; 7: 1959

35. Dubuc J, Duffield TF, Leslie KE, Walton JS, LeBlanc SJ. Definitions and diagnosis of postpartum endometritis in dairy cows. J Dairy Sci 2010; 93: 5225-5233. [Medline] [CrossRef]

36. Katagiri S, Moon YS, Yuen BH. The role for the uterine insulin-like growth factor I in early embryonic loss after superovulation in the rat. Fertil Steril 1996; 65: 426-436. [Medline] [CrossRef]

37. Bischof RJ, Lee CS, Brandon MR, Meeusen E. Inflammatory response in the pig uterus induced by seminal plasma. J Reprod Immunol 1994; 26: 131-146. [Medline] [CrossRef]

38. Portus BJ, Reilas T, Katila T. Effect of seminal plasma on uterine inflammation, contractility and pregnancy rates in mares. Equine Vet $J$ 2005; 37: 515-519. [Medline] [CrossRef]

39. Sharkey DJ, Macpherson AM, Tremellen KP, Mottershead DG, Gilchrist RB, Robertson SA. TGF- $\beta$ mediates proinflammatory seminal fluid signaling in human cervical epithelial cells. J Immunol 2012; 189: 1024-1035. [Medline] [CrossRef]

40. Ortiz WG, Rizo JA, Carvalheira LR, Ahmed BMS, Estrada-Cortes E, Harstine BR, Bromfield JJ, Hansen PJ. Effects of intrauterine infusion of seminal plasma at artificial insemination on fertility of lactating Holstein cows. J Dairy Sci 2019; 102: 6587-6594. [Medline] [CrossRef]

41. Katila T. Post-mating inflammatory responses of the uterus. Reprod Domest Anim 2012; 47(Suppl 5): 31-41. [Medline] [CrossRef]

42. Bromfield JJ. A role for seminal plasma in modulating pregnancy outcomes in domestic species. Reproduction 2016; 152: R223-R232. [Medline] [CrossRef]

43. Ibrahim LA, Rizo JA, Fontes PLP, Lamb GC, Bromfield JJ. Seminal plasma modulates expression of endometrial inflammatory meditators in the bovine. Biol Reprod 2019 100: 660-671. [Medline] [CrossRef]

44. Fernandez-Fuertes B, Sánchez JM, Bagés-Arnal S, McDonald M, Yeste M, Lonergan P. Species-specific and collection method-dependent differences in endometrial susceptibility to seminal plasma-induced RNA degradation. Sci Rep 2019; 9: 15072. [Medline] [CrossRef] 